\title{
Is Levodopa Pharmacokinetics in Patients with Parkinson's Disease Depending on Gastric Emptying?
}

\author{
Maria Nord1,2, Anita Kullman², Ulf Hannestad², Nil Dizdar ${ }^{1,2}$ \\ ${ }^{1}$ Department of Neurology, Linköping University, Linköping, Sweden \\ ${ }^{2}$ Department of Clinical and Experimental Medicine, Linköping University, Linköping, Sweden \\ Email:marianord82@gmail.com, anita.kullman@liu.se,ulf.hannestad@liu.se,nil.dizdar@regionostergotland.se
}

How to cite this paper: Nord, M., Kullman, A., Hannestad, U. and Dizdar, N. (2017) Is Levodopa Pharmacokinetics in Patients with Parkinson's Disease Depending on Gastric Emptying? Advances in Parkinson's Disease, 6, 1-12.

https://doi.org/10.4236/apd.2017.61001

Received: January 4, 2017

Accepted: February 3, 2017

Published: February 6, 2017

Copyright (C) 2017 by authors and Scientific Research Publishing Inc. This work is licensed under the Creative Commons Attribution International License (CC BY 4.0).

http://creativecommons.org/licenses/by/4.0/

\begin{abstract}
Levodopa uptake from the gastrointestinal tract in patients with Parkinson's disease (PD) can be affected by delayed gastric emptying (GE). This might lead to fluctuating levodopa levels resulting in increased motor fluctuations. Continuous dopaminergic stimulation (CDS) improves motor fluctuations and could be a result of smoothening in levodopa uptake. In this study we wanted to study the levodopa pharmacokinetics peripherally in PD patients with motor fluctuations and investigate the relation between levodopa uptake and GE and the effect of CDS. PD patients with wearing off (group 1) and on-off syndrome (group 2) were included. Breath tests were performed to evaluate the half time (T1/2) of GE. Concomitantly 1 tablet of Madopark ${ }^{\circledR}$ was given and the levodopa concentrations in blood and subcutaneous (SC) tissue were analyzed for both groups. Group 2 was then given a 10-d continuous intravenous levodopa treatment and the tests were repeated. Higher levels of levodopa in group 1 compared to group 2 in blood $(\mathrm{p}=0.014)$ were seen. The GE was delayed in both group $1(\mathrm{p}<0.001)$ and group $2(\mathrm{p}<0.05)$ compared to a reference group with healthy volunteers with T1/2 median values 105 and $78 \mathrm{~min}$ vs. $72 \mathrm{~min}$. There was no difference in GE between the two PD groups $(\mathrm{p}=0.220)$ or in group 2 before and after infusion period $(\mathrm{p}=0.861)$. CDS resulted in lower levodopa levels in blood $(\mathrm{p}<0.001)$ and SC tissue $(\mathrm{p}<0.01)$. In conclusion, $\mathrm{PD}$ patients in early complication phase have a more favourable levodopa uptake than patients later in disease. We found delayed GE in PD patients with motor fluctuations but no obvious relation between GE and levodopa uptake or GE and PD stage. The effect of CDS indicates no effect of CDS on the mechanisms of GE but on the mechanisms of levodopa uptake.
\end{abstract}

\section{Keywords}

Parkinson Disease, Levodopa, Gastric Emptying, Continuous Dopaminergic Stimulation, Microdialysis 


\section{Introduction}

Levodopa is still the gold standard in the treatment of patients with Parkinson's disease (PD) but there are several factors affecting the availability of levodopa. Orally given levodopa is absorbed in the proximal one-third of the small intestine and the competition between levodopa and other large neutral amino acids across the intestinal mucosa is therefore a factor [1] [2]. Another factor is the gastric emptying (GE) [3]. It has been shown that more than $70 \%$ of PD patients suffer from impaired gastric motility [4] [5] with symptoms like early satiety, postprandial bloating and nausea and it has been suggested that this is caused by the delay in GE that has been shown in PD patients [5]-[13]. Delayed GE has also been shown to impair the levodopa uptake and is therefore suggested to worsen motor fluctuations [4] [11] [14] [15] [16]. To optimize the conditions for levodopa on its way to the brain seems to be of great importance in preventing motor fluctuations. Previous studies have shown that continuous dopaminergic stimulation (CDS) seems to induce plasticity changes of the dopaminergic postsynaptic receptors reducing on-off syndrome [17] [18] [19] [20]. In the past years it has now been shown that CDS also is beneficial for some non-motor symptoms (NMS) in PD [20] [21] [22]. A question is if CDS can result in changes of the GE indicating a postsynaptic dependency of GE.

In this study, we wanted to investigate the pharmacokinetics of levodopa given orally in two groups of PD patients; one group in early complication phase with wearing off and one group with more severe disease with on-off syndrome. We also wanted to study if and how the GE rate differs in these different stages of $\mathrm{PD}$ and if there is a relation between GE and levodopa uptake. We also wanted to evaluate the effect on the pharmacokinetics of levodopa and GE after CDS given as a continuous intravenous (IV) levodopa infusion.

\section{Materials and Methods}

\subsection{Patients and Experimental Data}

Two groups of patients with PD were selected; see patient demography in Table 1 and Table 2. The PD diagnosis was made according to UK Parkinson's disease society brain bank criteria. Group 1 consisted of 16 patients with PD in early complication phase with wearing off symptoms. The patients had at least 4 tablet intakes per day and regular off periods before at least one of the doses. Group 2 included 14 patients with PD in severe stage of the disease and on-off syndrome with unpredictable and disabling dyskinesia. The patients were admitted to the ward and their PD medication was discontinued the night before the first test day. All GE data were compared to the laboratory reference material consisting of 50 healthy volunteers that was somewhat younger than our patients [23]. The study was performed with approval from the Regional Ethical Review Board in Linköping and informed consent was obtained from the patients.

In our study we used microdialysis on both blood and in subcutaneous (SC) tissue. Microdiaysis has been shown a lenient way of taking samples and allows frequent sampling during long periods of time. The microdialysis technique is 
Table 1. Demography of PD patients with wearing off (Group 1).

\begin{tabular}{|c|c|c|c|c|c|}
\hline $\begin{array}{l}\text { Patient } \\
\text { No }\end{array}$ & $\begin{array}{c}\text { Age } \\
\text { (years) }\end{array}$ & $\begin{array}{c}\text { Gender } \\
\text { F/M }\end{array}$ & $\begin{array}{c}\text { Duration of PD } \\
\text { (years) }\end{array}$ & $\begin{array}{l}\text { Levodopa dose } \\
(\mathrm{mg} / \mathrm{d})\end{array}$ & $\begin{array}{c}\text { Other } \\
\text { antiparkinsonian } \\
\text { medications }\end{array}$ \\
\hline 1 & 72 & M & 8 & 500 & cabergoline, selegiline \\
\hline 2 & 67 & $\mathrm{~F}$ & 16 & $900-1050$ & pramipexol, entacapone \\
\hline 3 & 52 & M & 16 & 1500 & - \\
\hline 4 & 62 & $\mathrm{~F}$ & 11 & 500 & cabergoline \\
\hline 5 & 65 & $\mathrm{~F}$ & 11 & 450 & selegiline \\
\hline 6 & 74 & M & 11 & 400 & pramipexol, selegiline \\
\hline 7 & 59 & M & 8 & $600-700$ & selegiline, entacapone \\
\hline 8 & 78 & M & 11 & 1100 & entacapone \\
\hline 9 & 73 & $\mathrm{~F}$ & 7 & 800 & entacapone \\
\hline 10 & 69 & $\mathrm{~F}$ & 13 & $1450-1700$ & entacapone \\
\hline 11 & 57 & $\mathrm{~F}$ & 6 & 950 & ropinirole, tolcapone \\
\hline 12 & 79 & M & 7 & 400 & pramipexol \\
\hline 13 & 69 & $\mathrm{~F}$ & 9 & 300 & tolcapone \\
\hline 14 & 75 & $\mathrm{~F}$ & 6 & 1000 & ropinirole, selegiline \\
\hline 15 & 69 & $\mathrm{~F}$ & 12 & $900-1100$ & cabergoline, tolcapone \\
\hline 16 & 67 & M & U.K. & 700 & tolcapone \\
\hline
\end{tabular}

Table 2. Demography of PD patients with on-off syndrome (Group 2).

\begin{tabular}{|c|c|c|c|c|c|}
\hline $\begin{array}{l}\text { Patient } \\
\text { No }\end{array}$ & $\begin{array}{c}\text { Age } \\
\text { (years) }\end{array}$ & $\begin{array}{c}\text { Gender } \\
\text { F/M }\end{array}$ & $\begin{array}{c}\text { Duration of PD } \\
\text { (years) }\end{array}$ & $\begin{array}{c}\text { Levodopa dose } \\
(\mathrm{mg} / \mathrm{d})\end{array}$ & $\begin{array}{l}\text { Other } \\
\text { antiparkinsonian } \\
\text { medications }\end{array}$ \\
\hline 1 & 78 & $\mathrm{~F}$ & U.K. & 400 & entacapone \\
\hline 2 & 57 & $\mathrm{~F}$ & 7 & 400 & pergolide, selegiline \\
\hline 3 & 61 & M & 16 & 950 & ropinirole, tolcapone \\
\hline 4 & 53 & M & 5 & $500-750$ & - \\
\hline 5 & 73 & $\mathrm{~F}$ & 11 & 800 & - \\
\hline 6 & 71 & M & 19 & $1575-1650$ & cabergoline, tolcapone \\
\hline 7 & 68 & $\mathrm{~F}$ & 18 & $400-500$ & pramipexol, selegiline \\
\hline 8 & 64 & M & 16 & $2150-2500$ & tolcapone \\
\hline 9 & 68 & M & 12 & 500 & tolcapone \\
\hline 10 & 67 & $\mathrm{~F}$ & 7 & $500-1000$ & cabergoline, entacapone \\
\hline 11 & 62 & M & 11 & 700 & - \\
\hline 12 & 59 & $\mathrm{~F}$ & 13 & 575 & ropinirole, entacapone \\
\hline 13 & 59 & $\mathrm{~F}$ & 14 & 800 & cabergoline, entacapone \\
\hline 14 & 70 & $\mathrm{M}$ & 8 & 550 & selegiline \\
\hline
\end{tabular}


based on passive diffusion across a semipermeable membrane from the tissue of interest to a perfusion fluid [24] and the analyzed concentration of the substance of interest reflects the interstitial concentration in the tissue. Microdialysis is possible to use in different tissues like blood, SC tissue and brain tissue [25] [26] [27]. We also used the octanoic acid breath test by Ghoos et al. [28], shown to be a reliable and safe method for evaluating the GE rate and suitable for patients in all stages of PD [23] [29] [30].

All patients from both groups performed the protocol of Day 1: A microdialysis probe was placed in a brachial vein and another probe was placed in the abdominal SC tissue. Baseline monitoring for microdialysis and breath test was performed before intake of an omelet containing a standardized amount of protein and ${ }^{13} \mathrm{C}$ marked octanoic acid. Together with the omelet the patients were given 1 tablet of Madopark ${ }^{\circledR}$ (100 mg of levodopa/25 mg of benserazide). During a period of $4 \mathrm{~h} \mathrm{IV} \mathrm{dialysates} \mathrm{and} \mathrm{breath} \mathrm{samples} \mathrm{were} \mathrm{taken} \mathrm{every} \mathrm{15-min} \mathrm{and} \mathrm{SC}$ dialysate fractions were collected every $30-\mathrm{min}$. The dialysate fractions were stored at $-20^{\circ} \mathrm{C}$ for 3 days at the most. The levodopa concentrations from IV and SC sampling were analyzed, without further clean-up [26] [31], with a highperformance liquid chromatography (HPLC) system with electrochemical detection [27]. The breath samples were stored in room temperature and the ${ }^{13} \mathrm{CO}_{2} /$ ${ }^{12} \mathrm{CO}_{2}$ ratio was analyzed with mass spectrometry [28]. T1/2, which represents the half-time of ${ }^{13} \mathrm{CO}_{2}$ elimination from the ventricle, was calculated.

Day 2 - 12: The patients from group 2 were also treated with continuous IV levodopa infusion, $5 \mathrm{mg} / \mathrm{mL}$ during $12 \mathrm{~h}$ daily for 10 days. The daily dose of levodopa infusion was calculated to correlate to the patient's oral medication. No other anti-PD medication was given during this time period. No side effects were observed during the treatment period. After the infusion period the patients underwent the same procedure as on Day 1 . The IV levodopa infusion was only given to patients with on-off syndrome since it was earlier described by Shoulson et al. to be beneficial for this group of patients by diminishing the on-off fluctuations.

\subsection{Exclusions}

Group 1: Patient no 1 was excluded from the study because of withdrawal of informed consent. Patient no 8 was excluded because of extra levodopa intake before study start.

Group 2: Patients no 4 and no 7 were excluded from both SC and IV microdialysis because of technical failure. However the results from the GE were included in the study for both patients. The IV microdialysis was not possible to perform in patients no 9 and no 10 due to fragile vessels. Patient no 14 was excluded from the study because of extra levodopa intake before study start.

\subsection{Statistics}

Nonparametric test was used for the analysis due to the small number of subjects. Related-samples Wilcoxon signed-rank test was used to analyze differences 
in the levodopa concentrations in blood and SC tissue within group 2. Independent Mann-Whitney $U$ test was used to analyze differences in the levodopa dose, levodopa concentrations and half time (T1/2) of GE between the two different PD groups and the reference group. Median values and box plot were also used to compare T1/2 of GE. We also compared group differences for area under the curve (AUC) for levodopa levels in blood and SC tissue $(\mu \mathrm{mol} \times \mathrm{min} / \mathrm{L})$. IBM SPSS Statistics 24 and Microsoft Excel were used for statistical analysis. $\mathrm{P}$ values below 0.05 were considered significant.

\section{Results}

The daily levodopa dose was similar in both groups $(\mathrm{p}=0.867)$. We found significantly higher levodopa concentrations in blood in group 1 ( $\mathrm{p}=0.014)$, with AUC 34.6 in group 1 compared to 25.7 in group 2. The results were similar for SC tissue but did not reach statistical significance $(p=0.050)$, AUC 19.3 in group 1 and 13.9 in group 2, Figure 1.

After the 10-day levodopa infusion period in group 2 slower levodopa uptake was observed and significantly lower concentrations of levodopa in both blood $(\mathrm{p}<0.001)$ and SC tissue $(\mathrm{p}<0.01)$ were seen compared to the levels before the infusion period, Figure 1. AUC for levodopa after the infusion period were 18.6 in blood and 9.6 in SC tissue.

The laboratory reference interval for T1/2 of GE was $47-99 \mathrm{~min}$, with the median value of T1/2 $72 \mathrm{~min}$. In group 1 the T1/2 median value was significantly higher compared to the reference group ( $\mathrm{p}<0.001$ ) with $105 \mathrm{~min}$, Figure 2 . The T1/2 median values in group 2 showed no significant difference before (78 $\mathrm{min}$ ) and after $(89 \mathrm{~min})$ the infusion period $(\mathrm{p}=0.861)$. However, compared to the reference group there were significant differences both before and after the infusion period ( $\mathrm{p}<0.05$ and $\mathrm{p}<0.01$ respectively), Figure 2 . No significant difference was seen between group 1 and $2(\mathrm{p}=0.220)$. When group 1 and group 2 , before the infusion period, were fused the T1/2 median value was significantly higher than the reference group ( $\mathrm{p}<0.0001$ ) with $100 \mathrm{~min}$ compared to $72 \mathrm{~min}$.

\section{Discussion}

Several factors may affect the uptake of levodopa. Delayed GE has been shown, by several authors, in PD patients [6] [7] [8] [10] [29] [32] and this seems to result in a lower levodopa bioavailability [4] [14] [15] [16]. Levodopa uptake from the GI tract can also be interfered by other amino acids that use the same transport carrier system as levodopa [33] [34]. The absorption of levodopa might also be affected by levodopa itself and Murata et al. showed, both in rats and in PD patients, that the absorption of levodopa from the gut is accelerated after long exposure to levodopa [35] [36]. Another interfering factor of levodopa uptake could be age since higher levodopa concentrations have been found in older patients [37] [38]. In our study, neither significant age difference (mean \pm SD $67.9 \pm$ 7.5 and $65.0 \pm 6.9$ years for group 1 and group 2 respectively) nor any obvious difference in levodopa treatment time in the two PD groups was seen. 


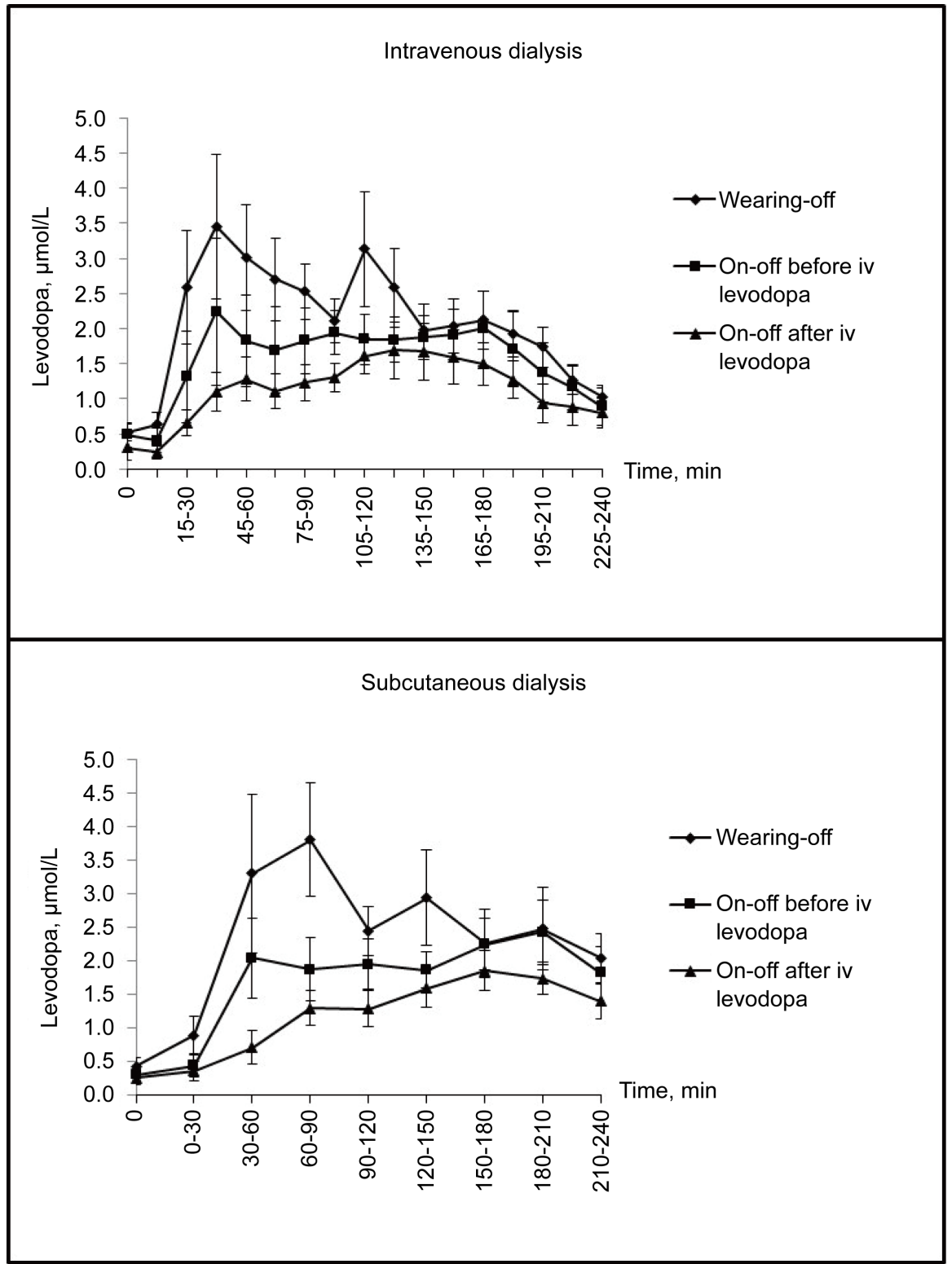

Figure 1. Levodopa concentrations (mean values) in blood and subcutaneous tissue from PD patients with wearing off (Group 1) and with on-off syndrome (Group 2) before and after 10 days of levodopa infusion treatment. Error bars representing standard error of the mean.

As expected we found higher levels of levodopa in patients with wearing off compared to the patients in more advanced stage of disease with on-off syndrome, Figure 1, indicating that PD patients with less severe disease have a better uptake of levodopa from the intestine. The levodopa curves in blood and SC tissue had very similar appearances but with a slight delay in the SC tissue. These results are similar to our previous findings [27]. Earlier studies have shown that the same delay applies for brain tissue [39] and SC monitoring of levodopa levels might therefore be more appropriate than blood concentration monitoring for clinical studies concerning correlation between levodopa levels and patient mobility. 


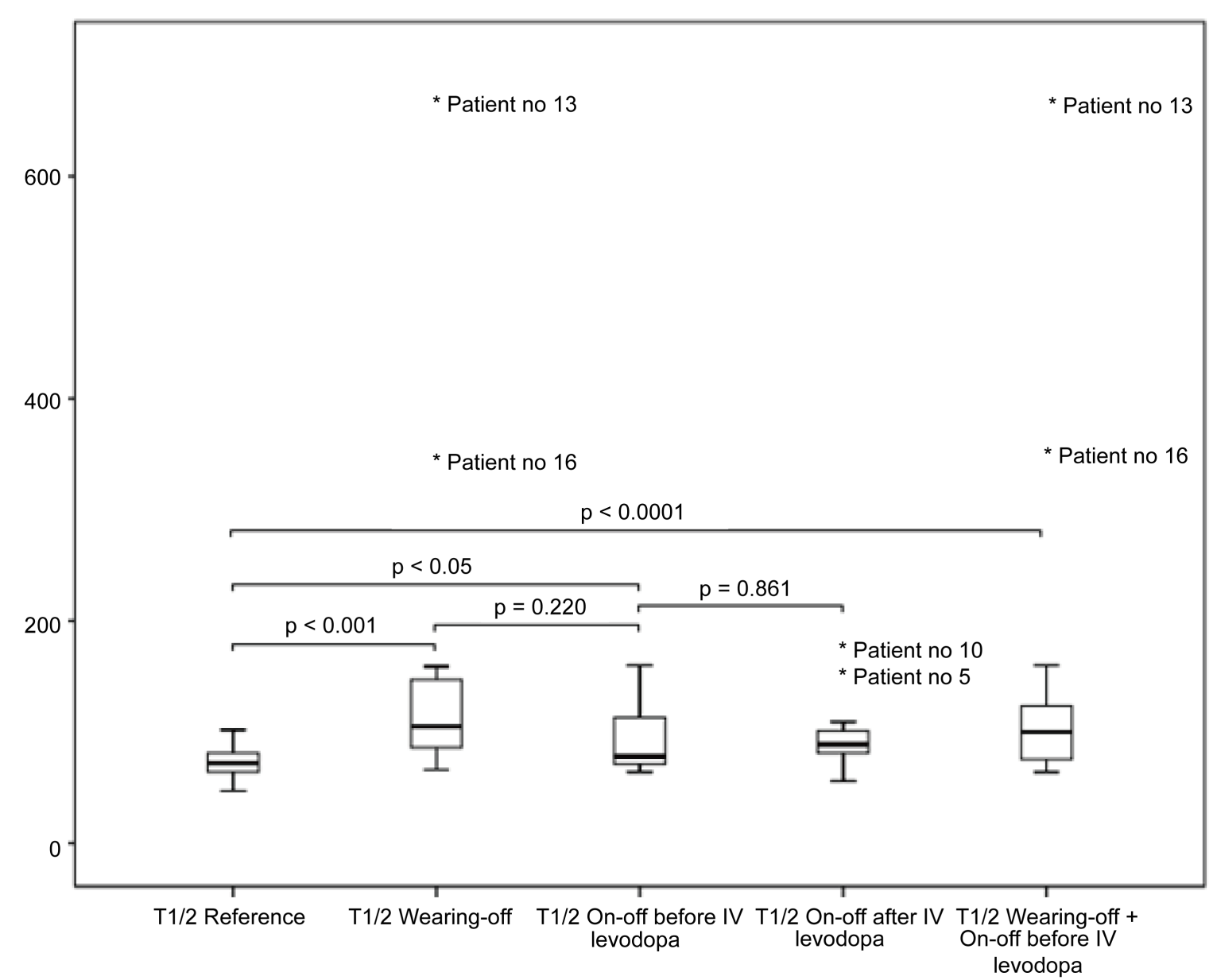

Figure 2. Boxplot for T1/2 of gastric emptying with significance levels ( $\mathrm{p}$ values) for reference group, PD patients with wearing off, PD patients with on-off syndrome before and after 10 days of levodopa infusion treatment and the two PD groups fused. Outliers $\left(^{*}\right)$ are also presented.

Our study did not show any significant difference in T1/2 of GE between the PD groups thus showing no obvious relation between levodopa uptake and GE in our study. However, it supports the theory of delayed GE in PD patients in complication phase showing significantly delayed T1/2 of GE in both PD groups compared to the reference group. The significance towards the reference group was even higher when both PD groups were fused. This is probably due to the increased number of patients.

No conclusive data have been presented in earlier studies about the relation between delayed GE and PD stage. Some studies have shown that delayed GE in PD patients is associated with disease severity [4] [29] while other studies cannot find any association of GE and disease duration or Hoehn and Yahr clinical scale [5] [6] [8]. Abnormalities in gastric motility have also been shown with electrogastrography in PD patients both in early and advanced stages of the disease [40] [41]. It is possible that there is no strict relation between severity of motor symptoms and degree of impairment of GE in PD patients. This is supported by our results where we could see no difference in GE between the two PD groups.

Previous studies have shown that CDS seems to induce plasticity changes of 
the dopaminergic postsynaptic receptors in brain reducing on-off syndrome [17] [18] [19] [20]. Figure 1 shows that the 10-day infusion period, with levodopa IV, resulted in significantly lower levodopa concentrations indicating an effect caused by CDS. We could not see any difference in GE before and after the infusion period and therefore we could not show any correlation between GE and levodopa uptake. The fact that the GE before and after the infusion period, did not differ, suggests that the mechanisms of GE are not influenced by CDS. More likely the GE is regulated locally in the GI tract.

One of the shortcomings in our study was that we did not register the motor symptoms before, during and after the 10-days infusion treatment, which would have been preferable since it could have provided more information about the CDS effect. The small number of participating patients in the two study groups could also have an impact on the results.

In conclusion, we could see significantly higher levels of levodopa in PD patients with wearing off compared to patients with on-off syndrome. The GE was significantly delayed in PD patients compared to the reference group but there was no difference between the two PD groups. We found no obvious relation between GE and levodopa uptake and CDS did not affect GE but it resulted in significantly decreased levodopa levels.

The relation between GE and levodopa uptake remains inconclusive and further studies are needed to elucidate the effect of GE on levodopa uptake and also the relation between GE and PD stage.

\section{Acknowledgements}

This study was supported by grants from the Research Foundation of the County Council of Östergötland, FORSS-Medical Research Council of Southeast Sweden, Swedish Parkinson Foundation, Futurum-the Academy for Healthcare of the County Council of Jönköping. We gratefully thank Karl Wahlin and Lars Valter at Linköping University for statistical guidance.

\section{Conflicts of Interest}

The authors declare that there is no conflict of interests regarding the publication of this paper.

\section{References}

[1] Khor, S.P. and Hsu, A. (2007) The Pharmacokinetics and Pharmacodynamics of Levodopa in the Treatment of Parkinson's Disease. Current Clinical Pharmacology, 2, 234-243. https://doi.org/10.2174/157488407781668802

[2] Nutt, J.G., Woodward, W.R., Hammerstad, J.P., Carter, J.H. and Anderson, J.L. (1984) The “On-Off” Phenomenon in Parkinson's Disease. Relation to Levodopa Absorption and Transport. The New England Journal of Medicine, 310, 483-488. https://doi.org/10.1056/NEJM198402233100802

[3] Nyholm, D., Odin, P., Johansson, A., Chatamra, K., Locke, C., Dutta, S. and Othman, A.A. (2013) Pharmacokinetics of Levodopa, Carbidopa, and 3-O-Methyldopa Following 16-Hour Jejunal Infusion of Levodopa-Carbidopa Intestinal Gel in Ad- 
vanced Parkinson's Disease Patients. The AAPS Journal, 15, 316-323. https://doi.org/10.1208/s12248-012-9439-1

[4] Djaldetti, R., Baron, J., Ziv, I. and Melamed, E. (1996) Gastric Emptying in Parkinson's Disease: Patients with and without Response Fluctuations. Neurology, 46, 1051-1054. https://doi.org/10.1212/WNL.46.4.1051

[5] Goetze, O., Nikodem, A.B., Wiezcorek, J., Banasch, M., Przuntek, H., Mueller, T., Schmidt, W.E. and Woitalla, D. (2006) Predictors of Gastric Emptying in Parkinson's Disease. Neurogastroenterology and Motility, 18, 369-375. https://doi.org/10.1111/j.1365-2982.2006.00780.x

[6] Tanaka, Y., Kato, T., Nishida, H., Yamada, M., Koumura, A., Sakurai, T., Hayashi, Y., Kimura, A., Hozumi, I., Araki, H., Murase, M., Nagaki, M., Moriwaki, H. and Inuzuka, T. (2010) Is There a Delayed Gastric Emptying of Patients with EarlyStage, Untreated Parkinson's Disease? An Analysis Using the (13)C-Acetate Breath Test. Journal of Neurology, 258, 421-426.

[7] Muller, T., Erdmann, C., Bremen, D., Schmidt, W.E., Muhlack, S., Woitalla, D. and Goetze, O. (2006) Impact of Gastric Emptying on Levodopa Pharmacokinetics in Parkinson Disease Patients. Clinical Neuropharmacology, 29, 61-67. https://doi.org/10.1097/00002826-200603000-00001

[8] Hardoff, R., Sula, M., Tamir, A., Soil, A., Front, A., Badarna, S., Honigman, S. and Giladi, N. (2001) Gastric Emptying Time and Gastric Motility in Patients with Parkinson's Disease. Movement Disorders, 16, 1041-1047. https://doi.org/10.1002/mds.1203

[9] Marrinan, S., Emmanuel, A.V. and Burn, D.J. (2014) Delayed Gastric Emptying in Parkinson's Disease. Movement Disorders, 29, 23-32. https://doi.org/10.1002/mds.25708

[10] Fasano, A., Bove, F., Gabrielli, M., Petracca, M., Zocco, M.A., Ragazzoni, E., Barbaro, F., Piano, C., Fortuna, S., Tortora, A., Di Giacopo, R., Campanale, M., Gigante, G., Lauritano, E.C., Navarra, P., Marconi, S., Gasbarrini, A. and Bentivoglio, A.R. (2013) The Role of Small Intestinal Bacterial Overgrowth in Parkinson's Disease. Movement Disorders, 28, 1241-1249. https://doi.org/10.1002/mds.25522

[11] Mukherjee, A., Biswas, A. and Das, S.K. (2016) Gut Dysfunction in Parkinson's Disease. World Journal of Gastroenterology, 22, 5742-5752.

https://doi.org/10.3748/wjg.v22.i25.5742

[12] Sung, H.Y., Park, J.W. and Kim, J.S. (2014) The Frequency and Severity of Gastrointestinal Symptoms in Patients with Early Parkinson's Disease. Journal of Movement Disorders, 7, 7-12. https://doi.org/10.14802/jmd.14002

[13] Pellegrini, C., Antonioli, L., Colucci, R., Ballabeni, V., Barocelli, E., Bernardini, N., Blandizzi, C. and Fornai, M. (2015) Gastric Motor Dysfunctions in Parkinson's Disease: Current Pre-Clinical Evidence. Parkinsonism \& Related Disorders, 21, 1407-1414. https://doi.org/10.1016/j.parkreldis.2015.10.011

[14] Kurlan, R., Rothfield, K.P., Woodward, W.R., Nutt, J.G., Miller, C., Lichter, D. and Shoulson, I. (1988) Erratic Gastric Emptying of Levodopa May Cause "Random" Fluctuations of Parkinsonian Mobility. Neurology, 38, 419-421. https://doi.org/10.1212/WNL.38.3.419

[15] Deleu, D., Ebinger, G. and Michotte, Y. (1991) Clinical and Pharmacokinetic Comparison of Oral and Duodenal Delivery of Levodopa/Carbidopa in Patients with Parkinson's Disease with a Fluctuating Response to Levodopa. European Journal of Clinical Pharmacology, 41, 453-458. https://doi.org/10.1007/BF00626368

[16] Doi, H., Sakakibara, R., Sato, M., Masaka, T., Kishi, M., Tateno, A., Tateno, F., Tsuyusaki, Y. and Takahashi, O. (2012) Plasma Levodopa Peak Delay and Impaired 
Gastric Emptying in Parkinson's Disease. Journal of the Neurological Sciences, 319, 86-88. https://doi.org/10.1016/j.jns.2012.05.010

[17] Mouradian, M.M., Heuser, I.J., Baronti, F. and Chase, T.N. (1990) Modification of Central Dopaminergic Mechanisms by Continuous Levodopa Therapy for Advanced Parkinson's Disease. Annals of Neurology, 27, 18-23. https://doi.org/10.1002/ana.410270105

[18] Stocchi, F., Ruggieri, S., Vacca, L. and Olanow, C.W. (2002) Prospective Randomized Trial of Lisuride Infusion versus Oral Levodopa in Patients with Parkinson's Disease. Brain, 125, 2058-2066. https://doi.org/10.1093/brain/awf214

[19] Stocchi, F., Vacca, L., Ruggieri, S. and Olanow, C.W. (2005) Intermittent vs Continuous Levodopa Administration in Patients with Advanced Parkinson Disease: A Clinical and Pharmacokinetic Study. Archives of Neurology, 62, 905-910. https://doi.org/10.1001/archneur.62.6.905

[20] Timpka, J., Mundt-Petersen, U. and Odin, P. (2016) Continuous Dopaminergic Stimulation Therapy for Parkinson's Disease-Recent Advances. Current Opinion in Neurology, 29, 474-479. https://doi.org/10.1097/WCO.0000000000000354

[21] Honig, H., Antonini, A., Martinez-Martin, P., Forgacs, I., Faye, G.C., Fox, T., Fox, K., Mancini, F., Canesi, M., Odin, P. and Chaudhuri, K.R. (2009) Intrajejunal Levodopa Infusion in Parkinson's Disease: A Pilot Multicenter Study of Effects on Nonmotor Symptoms and Quality of Life. Movement Disorders, 24, 1468-1474. https://doi.org/10.1002/mds.22596

[22] Reddy, P., Martinez-Martin, P., Rizos, A., Martin, A., Faye, G.C., Forgacs, I., Odin, P., Antonini, A. and Chaudhuri, K.R. (2012) Intrajejunal Levodopa versus Conventional Therapy in Parkinson Disease: Motor and Nonmotor Effects. Clinical Neuropharmacology, 35, 205-207. https://doi.org/10.1097/WNF.0b013e3182613dea

[23] Dizdar, N., Granerus, A.K., Hannestad, U., Kullman, A., Ljungdahl, A., Olsson, J.E. and Kagedal, B. (1999) L-Dopa Pharmacokinetics Studied with Microdialysis in Patients with Parkinson's Disease and a History of Malignant Melanoma.. Acta Neurologica Scandinavica, 100, 231-237. https://doi.org/10.1111/j.1600-0404.1999.tb00386.x

[24] Ungerstedt, U. (1991) Microdialysis-Principles and Applications for Studies in Animals and Man. Journal of Internal Medicine, 230, 365-373. https://doi.org/10.1111/j.1365-2796.1991.tb00459.x

[25] Meyerhoff, C., Bischof, F., Mennel, F.J., Sternberg, F. and Pfeiffer, E.F. (1993) Use of the Microdialysis Technique in the Monitoring of Subcutaneous Tissue Glucose Concentration. The International journal of Artificial Organs, 16, 268-275.

[26] Paez, X. and Hernandez, L. (1997) Blood Microdialysis in Humans: A New Method for Monitoring Plasma Compounds. Life Sciences, 61, 847-856. https://doi.org/10.1016/S0024-3205(97)00586-9

[27] Dizdar, N., Kullman, A., Norlander, B., Olsson, J.E. and Kagedal, B. (1999) Human Pharmacokinetics of L-3,4-Dihydroxyphenylalanine Studied with Microdialysis. Clinical Chemistry, 45, 1813-1820.

[28] Ghoos, Y.F., Maes, B.D., Geypens, B.J., Mys, G., Hiele, M.I., Rutgeerts, P.J. and Vantrappen, G. (1993) Measurement of Gastric Emptying Rate of Solids by Means of a Carbon-Labeled Octanoic Acid Breath Test. Gastroenterology, 104, 1640-1647. https://doi.org/10.1016/0016-5085(93)90640-X

[29] Goetze, O., Wieczorek, J., Mueller, T., Przuntek, H., Schmidt, W.E. and Woitalla, D. (2005) Impaired Gastric Emptying of a Solid Test Meal in Patients with Parkinson's Disease Using 13C-Sodium Octanoate Breath Test. Neuroscience Letters, 375, 170 173. https://doi.org/10.1016/j.neulet.2004.11.007 
[30] Meier, J.J., Gallwitz, B., Salmen, S., Goetze, O., Holst, J.J., Schmidt, W.E. and Nauck, M.A. (2003) Normalization of Glucose Concentrations and Deceleration of Gastric Emptying after Solid Meals during Intravenous Glucagon-Like Peptide 1 in Patients with Type 2 Diabetes. The Journal of Clinical Endocrinology and Metabolism, 88, 2719-2725. https://doi.org/10.1210/jc.2003-030049

[31] O'Connell, M.T., Tison, F., Quinn, N.P. and Patsalos, P.N. (1996) Clinical Drug Monitoring by Microdialysis: Application to Levodopa Therapy in Parkinson's Disease. British Journal of Clinical Pharmacology, 42, 765-769. https://doi.org/10.1046/j.1365-2125.1996.00505.x

[32] Krygowska-Wajs, A., Cheshire Jr., W.P., Wszolek, Z.K., Hubalewska-Dydejczyk, A., Jasinska-Myga, B., Farrer, M.J., Moskala, M. and Sowa-Staszczak, A. (2009) Evaluation of Gastric Emptying in Familial and Sporadic Parkinson Disease. Parkinsonism \& Related Disorders, 15, 692-696. https://doi.org/10.1016/j.parkreldis.2009.04.003

[33] Contin, M. and Martinelli, P. (2010) Pharmacokinetics of Levodopa. Journal of Neurology, 257, S253-S261. https://doi.org/10.1007/s00415-010-5728-8

[34] Lennernas, H., Nilsson, D., Aquilonius, S.M., Ahrenstedt, O., Knutson, L. and Paalzow, L.K. (1993) The Effect of L-Leucine on the Absorption of Levodopa, Studied by Regional Jejunal Perfusion in Man. British Journal of Clinical Pharmacology, 35, 243-250. https://doi.org/10.1111/j.1365-2125.1993.tb05691.x

[35] Murata, M. and Kanazawa, I. (1993) Repeated L-Dopa Administration Reduces the Ability of Dopamine Storage and Abolishes the Supersensitivity of Dopamine Receptors in the Striatum of Intact Rat. Neuroscience Research, 16, 15-23. https://doi.org/10.1016/0168-0102(93)90004-A

[36] Murata, M., Mizusawa, H., Yamanouchi, H. and Kanazawa, I. (1996) Chronic Levodopa Therapy Enhances Dopa Absorption: Contribution to Wearing-Off. Journal of Neural Transmission, 103, 1177-1785. https://doi.org/10.1007/BF01271202

[37] Robertson, D.R., Wood, N.D., Everest, H., Monks, K., Waller, D.G., Renwick, A.G. and George, C.F. (1989) The Effect of Age on the Pharmacokinetics of Levodopa Administered Alone and in the Presence of Carbidopa. British Journal of Clinical Pharmacology, 28, 61-69. https://doi.org/10.1111/j.1365-2125.1989.tb03506.x

[38] Iwamoto, K., Watanabe, J. and Atsumi, F. (1987) Age Dependence in CapacityLimited Jejunal Decarboxylation of Levodopa in Rats. Biochemical Pharmacology, 36, 2151-2155. https://doi.org/10.1016/0006-2952(87)90144-4

[39] Zsigmond, P., Dernroth, N., Kullman, A., Augustinsson, L.E. and Dizdar, N. (2012) Stereotactic Microdialysis of the Basal Ganglia in Parkinson's Disease. Journal of Neuroscience Methods, 207, 17-22. https://doi.org/10.1016/j.jneumeth.2012.02.021

[40] Krygowska-Wajs, A., Lorens, K., Thor, P., Szczudlik, A. and Konturek, S. (2000) Gastric Electromechanical Dysfunction in Parkinson's Disease. Functional Neurology, 15, 41-46.

[41] Soykan, I., Lin, Z., Bennett, J.P. and McCallum, R.W. (1999) Gastric Myoelectrical Activity in Patients with Parkinson's Disease: Evidence of a Primary Gastric Abnormality. Digestive Diseases and Sciences, 44, 927-931.

https://doi.org/10.1023/A:1026648311646 


\section{Abbreviation list}

AUC: Area under the curve

CDS: Continuous dopaminergic stimulation

GE: Gastric emptying

T1/2: Half time

HPLC: High-performance liquid chromatography

IV: Intravenous

NMS: Non-motor symptoms

PD: Parkinson's disease

SC: Subcutaneous

Submit or recommend next manuscript to SCIRP and we will provide best service for you:

Accepting pre-submission inquiries through Email, Facebook, LinkedIn, Twitter, etc. A wide selection of journals (inclusive of 9 subjects, more than 200 journals)

Providing 24-hour high-quality service

User-friendly online submission system

Fair and swift peer-review system

Efficient typesetting and proofreading procedure

Display of the result of downloads and visits, as well as the number of cited articles

Maximum dissemination of your research work

Submit your manuscript at: http://papersubmission.scirp.org/

Or contact apd@scirp.org 